JURNAL

\title{
SURAT PERINTAH PENGHENTIAN PENYIDIKAN (SP3) DALAM PEMBERANTASAN TINDAK PIDANA KORUPSI
}

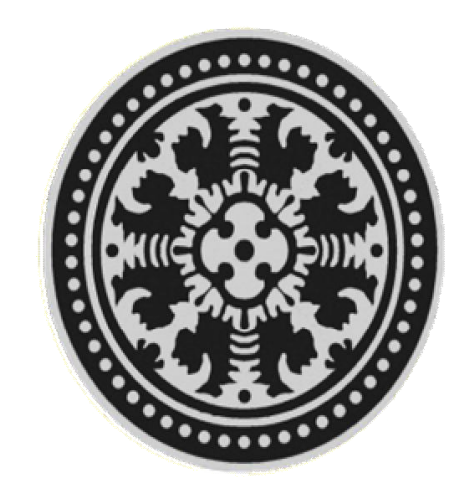

IDEWA GEDE DANA SUGAMA NIM. 1190561004

PROGRAM PASCASARJANA

PROGRAM STUDI MAGISTER (S2) ILMU HUKUM

UNIVERSITAS UDAYANA

DENPASAR

2014 


\section{SURAT PERINTAH PENGHENTIAN PENYIDIKAN (SP3) DALAM PEMBERANTASAN TINDAK PIDANA KORUPSI}

\section{Oleh}

\section{DEWA GEDE DANA SUGAMA}

This study discusses about Inadequacy Corruption Eradication Commission In Issuing Warrant Termination of Investigation In Corruption Case. The Commission is authorized to issue a warrant termination of the investigation and to determine the actions taken when the Commission which investigated corruption Commission was not enough evidence.

The conclusion of this study is, first Corruption Eradication Commission is authorized to issue an Order for Termination of Investigation in accordance with Article 40 of Law No. 30 Year 2002 about Corruption Eradication Commission, consideration of the logic of juridical is that the Commission is not a core law enforcement within the criminal justice system and just as independent institutions that can be dismissed if there is no corruption in our country. The arrangement of Article 40 of Law No. 30 of 2002 is prudential or attitude of prudence principle for the Commission to work accurately, efficiently and professionally.

key word : Corruption Eradication Commission, Termination Warrant Investigation, Corruption. 


\section{BAB 1 \\ PENDAHULUAN}

\section{PENDAHULUAN}

\subsection{Latar Belakang Masalah}

Peningkatan kasus korupsi di Indonesia saat ini sudah sangat memprihatinkan. Tidak hanya kerugian keuangan negara yang ditimbulkan, namun berdampak pula kepada perekonomian kehidupan masyarakat. Hak sosial dan ekonomi masyarakat pada umumnya telah dilanggar berkaitan dengan kasus korupsi yang kini sulit dibendung.

Tindak pidana korupsi kini digolongkan sebagai extra ordinary crime atau kejahatan luar biasa yang memberi dampak sistematis. Penegakan hukum dalam penanggulangannya pun kini dilakukan dengan cara-cara yang luar biasa, diluar dari proses konvensional yang selama ini dilakukan.

Negara Republik Indonesia adalah Negara Hukum, sehingga segala sesuatu mesti berdasarkan pada aturanaturan hukum, terutama sekali diperlukan adanya aparat penegak hukum yang diberi tugas, fungsi dan kewenangan menurut aturan hukum yang secara formil merupakan landasan dan dasar legitimasinya untuk menegakkan hukum. Dalam Penanggulangan kasus korupsi, dalam hal ini kewenangan sebagai penyidik dilakukan oleh Kepolisian dan Kejaksaan termasuk pula oleh Komisi Pemberantasan Korupsi (KPK).

Dibentuknya

Komisi

Pemberantasan Tindak Pidana Korupsi (KPK) didasari oleh ketentuan Pasal 43 Undang-Undang Nomor 31 Tahun 1999 tentang Pemberantasan Tindak Pidana Korupsi sebagaimana telah diubah dengan Undang-Undang Nomor 20 Tahun 2001, dimana dalam ayat 1 berbunyi "Dalam waktu paling lambat 2 (dua) tahun sejak Undang-undang ini mulai berlaku, dibentuk Komisi Pemberantasan Tindak Pidana Korupsi”.

Pasal 3 Undang-Undang Nomor 30 Tahun 2002 tentang KPK. menyebutkan KPK adalah "Lembaga negara yang dalam melaksanakan tugas dan wewenangnya bersifat independen dan bebas dari pengaruh kekuasaan manapun”. Kekuasaan manapun yang dimaksud yakni semua aspek yang dapat mempengaruhi tugas dan wewenang KPK atau anggota Komisi secara individu baik dari pihak legislatif, eksekutif, yudikatif, maupun 
pihak lain yang berkaitan dengan kasus korupsi yang sedang atau akan ditangani.

Pasal 40 Undang-Undang No 30

Tahun 2002 tentang KPK berbunyi "Komisi Pemberantasan Korupsi tidak berwenang mengeluarkan surat perintah penghentian penyidikan dan penuntutan dalam perkara tindak pidana korupsi”. Dari rumusan pasal diatas terdapat perbedaan kewenangan proses penyidikan yang dilakukan oleh KPK, dengan kewenangan sebagai penyidik yang dilakukan oleh Kepolisian maupun Kejaksaan. KPK tidak berwenang mengeluarkan SP3 maupun SKP2 dalam setiap penyidikan yang dilakukannya.

Ketentuan dalam pasal tersebut diatas tentu saja dinilai tidak adil oleh para tersangka yang sedang terjerat kasus korupsi yang sedang ditangani oleh KPK. Tanpa adanya proses SP3 para tersangka akan dilanjutkan kasusnya sampai ke tingkat pengadilan.

Sehubungan dengan Pasal 40

UU KPK yang meniadakan wewenang KPK dalam mengeluarkan SP3 terjadi konflik norma, dimana dalam ketentuan KUHAP sebagaimana diatur dalam Pasal 109 ayat (2) memberi wewenang kepada penyidik untuk menghentikan penyidikan yang sedang berjalan, ketentuan ini bisa mengundang berbagai polemik apabila proses penyidikan kasus tindak pidana korupsi yang ditangani KPK tidak diperoleh bukti yang cukup.

Sehubungan tentang ketentuan diatas yang menyebutkan melanggar hak asasi manusia, Menurut Manfred Nowak dalam bukunya berjudul Introduction to the International Human Rights Regimen menyebutkan What are Human Right?:

1. Those fundamental rights, which empower human beings to shape their lives in accordance with liberty, equality and respect for human dignity.

2. The sum of civil, political, economic, social, cultural and collective rights laid down in international and regional human rights instruments, and in the constitutions of states.

3. The only universally recognized value system under present international law comprising elements of liberalism, democracy, popular participation, social justice, the rule of law and good governance. ${ }^{1}$

Dalam terjemahan bebas diatas yakni Apakah yang dimaksud dengan Hak Asasi Manusia?

\footnotetext{
1 Manfred Nowak, 2002, Introduction to the International Human Rights Regimen, Brill Academic Publishers, USA, p. 1.
} 
1. Hak-hak fundamental, yang memberdayakan manusia untuk membentuk kehidupan mereka sesuai dengan kebebasan, kesetaraan dan penghormatan terhadap martabat manusia.

2. Jumlah sipil, hak politik, ekonomi, sosial, budaya dan kolektif ditetapkan dalam instrumen hak asasi manusia internasional dan regional, dan dalam konstitusi negara.

3. Satu-satunya yang diakui secara universal sistem nilai di bawah hukum internasional saat ini terdiri dari unsur liberalisme, demokrasi, partisipasi rakyat, keadilan sosial, aturan hukum dan tata pemerintahan yang baik.

\subsection{Rumusan Masalah}

Berdasarkan latar belakang masalah diatas, rumusan masalah yang dapat diambil adalah sebagai berikut :

1. Mengapa KPK tidak diberi wewenang mengeluarkan surat perintah penghentian penyidikan (SP3)?

\subsection{Tujuan}

Tujuan khusus dari jurnal ini adalah bertujuan untuk meneliti tentang ketidakwenangan KPK dalam mengeluarkan SP3 pada perkara korupsi di Indonesia.

\section{METODE PENELITIAN}

Penyusunan penelitian ini mempergunakan jenis penelitian normatif. "Penelitian hukum normatif disebut juga penelitian hukum doktrinal. Pada penelitian hukum ini acapkali hukum dikonsepkan sebagai apa yang tertulis dalam peraturan perundangundangan (law in books) atau hukum dikonsepkan sebagai kaidah atau norma yang merupakan patokan berperilaku manusia yang dianggap pantas. “2

Adapun jenis pendekatan yang dipergunakan yaitu Pendekatan historis (Historical Approach). Pendekatan historis dilakukan dalam kerangka sejarah lembaga hukum dari waktu ke waktu. Pendekatan ini sangat membantu peneliti untuk memahami filosofi dari aturan hukum dari waktu ke waktu. ${ }^{3}$

\section{HASIL DAN PEMBAHASAN}

3.1. Surat Perintah Penghentian Penyidikan (SP3)

SP3 adalah Surat Perintah

Penghentian Penyidikan atau lazim

2 Amiruddin dan Zainal Asikin, 2008, Pengantar Metode Penelitian Hukum, Cet 4, PT Raja Grafindo Persada, Jakarta, h. 118.

${ }^{3}$ Peter Mahmud Marzuki, 2006, Penelitian Hukum, Kencana Prenada Media Group, Jakarta, h. 126. 
disingkat SP3. SP3 merupakan surat pemberitahuan dari penyidik pada penuntut umum bahwa perkara dihentikan penyidikannya. SP3 menggunakan formulir yang telah ditentukan dalam Keputusan Jaksa Agung No. 518/A/J.A/11/2001 tanggal 1 Nopember 2001 tentang Perubahan Keputusan Jaksa Agung Republik Indonesia No. 132/JA/11/1994 tentang Administrasi Perkara Tindak Pidana. ${ }^{4}$

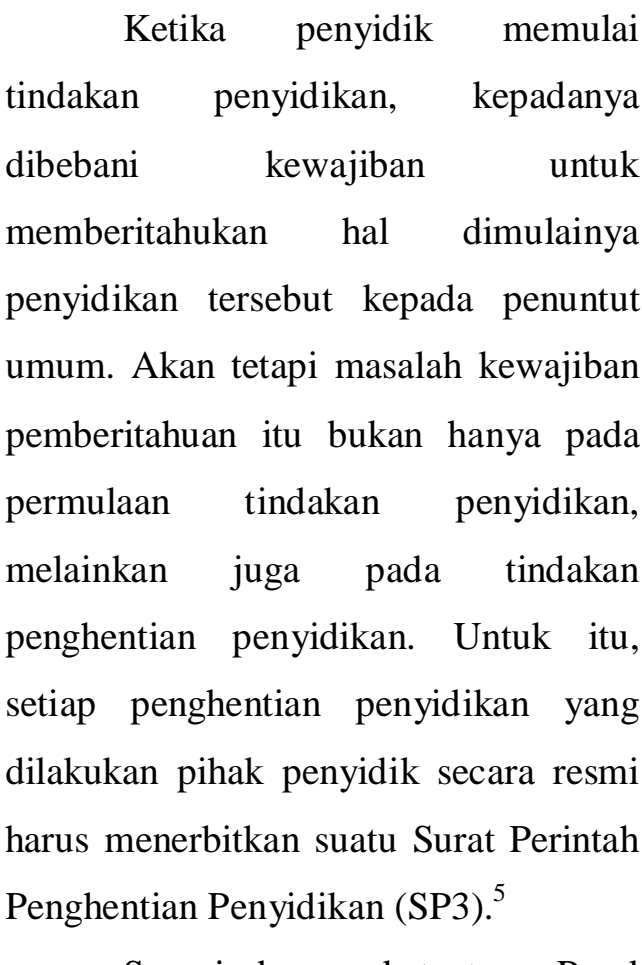
Sesuai dengan ketentuan Pasal 109 ayat (1) KUHAP, penyidik

\begin{tabular}{ccc}
\hline 4 & Shanti Rachmadsyah, SP3,
\end{tabular}
( 4, diakses Kamis 31 Oktober 2013.

5 Lilik Mulyadi, 2007, Hukum Acara Pidana Normatif, Teoritis, Praktik dan Permasalahannya, P.T. Alumni, Bandung, h. 54. menyampaikan pemberitahuan kepada penuntut umum apabila penyidik telah mulai melakukan tindakan penyidikan. Pemberitahuan itu merupakan pelaksanaan yang harus dilakukan penyidik bersamaan dengan tindakan yang dilakukannya. Sebagaimana yang ditegaskan, pemberitahuan penyidikan kepada penuntut umum, dianggap kewajiban yang harus dilakukan dengan cara tertulis maupun lisan yang disusul kemudian dengan tulisan. Dalam praktik sering terjadi adanya pemberitahuan dimulainya penyidikan yang berlarut-larut tanpa penyelesaian. Apakah penyidikan ini dihentikan atau berkasnya diserahkan ke penuntut umum. Untuk mengatasi permasalahan ini diperlukan rumusan yang jelas mengenai pemberitahuan perkembangan penyidikan yakni :

1. penyidik memberitahukan tentang perkembangan penyidikan kepada penuntut umum, atau

2. penuntut umum minta penjelasan kepada penyidik atas perkembangan penyidikan. ${ }^{6}$

Dalam pasal 109 ayat (2) diatur mengenai alasan dilakukannya penghentian penyidikan yakni :

\footnotetext{
${ }^{6}$ Husein Harun M, 1991, Penyidikan dan Penuntutan Dalam Proses Pidana, Rineka Cipta, Jakarta, h. 29.
} 
1. Tidak diperoleh bukti yang cukup, yaitu apabila penyidik tidak memperoleh cukup bukti untuk menuntut tersangka atau bukti yang diperoleh penyidik tidak memadai untuk membuktikan kesalahan tersangka.

2. Peristiwa yang disangkakan bukan merupakan tindak pidana.

3. Penghentian penyidikan demi hukum. Alasan ini dapat dipakai apabila ada alasanalasan hapusnya hak menuntut dan hilangnya hak menjalankan pidana, yaitu antara lain karena nebis in idem, tersangka meninggal dunia, atau karena perkara pidana telah kedaluwarsa.

Dalam proses penghentian penyidikan, Keberlakuan KUHAP merupakan realisasi dan unifikasi dan kodifikasi dalam bidang hukum acara pidana. Tujuannya agar masyarakat dapat menghayati kewajiban dan haknya dan pembinaan sikap para penegak hukum sesuai fungsi dan wewenangnya. ${ }^{7}$

7 Djoko Prakoso, 1987, Penyidik, Penuntut Umum, Hakim, Dalam Proses Hukum Acara Pidana, Bina Aksara, Jakarta, h. 5.

Terdapat asas yang penting
dalam KUHAP yakni adanya
pengawasan secara horizontal dalam
proses penegakan hukum. Yang
dimaksud yakni adanya pengawasan
timbal balik antar penegak hukum.
Dimana aparat penegak hukum dapat
mengawasi dan menguji proses
penghentian penyidikan satu sama lain.
3.2. KPK Sebagai Penyidik Tindak
Pidana Korupsi

Secara etimologi korupsi merupakan istilah dari bahasa latin, yakni corruptio atau corruptos yang bila diterjemahkan secara harfiah adalah pembusukan, keburukan, kebejatan, ketidakjujuran, dapat disuap, tidak bermoral, menyimpang dari kesucian, kata-kata atau ucapan yang memfitnah. Meskipun kata corruptio memiliki arti luas, namun sering diartikan sebagai penyuapan, istilah korupsi disimpulkan dalam bahasa Indonesia oleh Purwadarmita dalam kamus umum bahasa Indonesia, korupsi adalah perbuatan buruk seperti penggelapan uang, penerimaan uang sogok. ${ }^{8}$

Menurut Andi Hamzah arti kata korupsi adalah kebusukan, keburukan, kebejatan, ketidakjujuran, dapat disuap,

8 Firman Wijaya, 2008, Peradilan Korupsi Teori dan Praktik, Maharani Press, Jakarta, h.7 
tidak bermoral, penyimpangan dari kesucian, kata-kata yang menghina atau memfitnah. ${ }^{9}$

Tindak pidana korupsi termasuk ke dalam tindak pidana khusus karena bersumber pada peraturan perundangundangan di luar KUHP. ${ }^{10}$ Pengertian tindak pidana korupsi juga telah dirumuskan oleh pemerintah didalam UU Nomor 31 Tahun 1999 jo UU Nomor 20 Tahun 2001 tentang Pemberantasan Tindak Pidana Korupsi, pada Pasal 2 ayat (1) menyatakan "Setiap orang yang secara melawan hukum melakukan perbuatan memperkaya diri sendiri atau orang lain atau suatu korporasi yang dapat merugikan keuangan negara atau perekonomian negara, dipidana dengan pidana penjara seumur hidup atau pidana penjara paling singkat 4 (empat) tahun dan paling lama 20 (dua puluh) tahun dan denda paling sedikit Rp. 200.000.000,- (dua ratus juta rupiah) dan paling banyak Rp. 1.000.000.000,(satu milyar rupiah)"

Sejak awal pemerintahan orde baru, Presiden Soeharto sudah

9 Andi Hamzah, 1991, Korupsi di Indonesia, Masalah dan Pemecahannya, Jilid 1, Cet. 3, Gramedia, Jakarta, h.9.

10 Adami Chazawi, 2006, Hukum Pembuktian Tindak Pidana Korupsi, PT. Alumni, Bandung, h. 1. membentuk beberapa komisi anti korupsi dalam usaha pemberantasan korupsi, di antaranya pada tahun 1967 dibentuk Tim Pemberantasan Korupsi yang berada di bawah Kejaksaan Agung dan pada tahun 1970, pemerintah juga pernah membentuk komisi empat di mana komisi ini bertugas untuk menemukan penyimpangan di Pertamina, Bulog, dan penebangan hutan. $^{11}$ Pada masa pemerintahan Abdurahman Wahid sebagai presiden juga pernah dibentuklah Tim Gabungan Pemberantasan Tindak Pidana Korupsi yang disingkat (TGPTPK), di mana lembaga ini merupakan lembaga tidak tetap atau sumir sampai Komisi Pemberantasan Korupsi terbentuk. Namun keberadaan lembaga-lembaga tersebut sepertinya belum juga dapat memuaskan masyarakat dilihat dari kinerja dan hasil yang diberikan oleh lembaga-lembaga tersebut.

Pembentukan KPK merupakan pelaksanaan dari Pasal 43 UndangUndang No 31 Tahun 1999 tentang Pemberantasan Tindak Pidana Korupsi sebagaimana telah diubah dengan Undang-Undang No 21 Tahun 2001 tentang Perubahan atas Undang-Undang

11 Teten Masduki dan Danang Widyoko, 2005, Menunggu Gebrakan KPK, Jentera Jilid VIII, Cet 3, Sinar Grafika, Jakarta, h. 42. 
No 31 Tahun 1999 tentang Pemberantasan Tindak Pidana Korupsi, dimana dinyatakan perlu dibentuk Komisi Pemberantasan Tindak Pidana Korupsi yang independen dengan tugas dan wewenang melakukan pemberantasan tindak pidana korupsi, meskipun terjadi keterlambatan waktu pembentukannya. Selain itu dibentuknya KPK juga dilatarbelakangi alasan karena lembaga pemerintah yang menangani perkara tindak pidana korupsi belum berfungsi secara efisien dan efektif dalam memberantas tindak pidana korupsi. ${ }^{12}$

Jaksa dan Kepolisian dianggap tidak efektif dalam menyelesaikan berbagai perkara tindak pidana korupsi, begitu pula dengan lembaga lain yang sebelumnya telah ada. Banyaknya kasus korupsi yang melibatkan aparat penegak hukum menyebabkan kepercayaan masyarakat terhadap aparat penegak hukum menjadi rendah.

Karena itulah KPK, sebagai lembaga negara yang dalam melaksanakan tugas dan wewenangnya bersifat independen dan bebas dari pengaruh kekuasaan manapun memiliki

12 Lilik Mulyadi, 2007, Tindak Pidana Korupsi di Indonesia, Normatif, Teoritis, Praktik dan Masalahnya, P.T. Alumni, Bandung, h. 23. kewenangan yang luar biasa, berdasarkan pada klasifikasi tindak pidana korupsi sebagai kejahatan yang luar biasa. ${ }^{13}$

Komisi Pemberantasan Korupsi merupakan lembaga Negara yang bersifat independen, melaksanakan tugas dan wewenangnya bebas dari kekuasaan manapun. Dalam ketentuan ini yang dimaksud dengan 'kekuasaan manapun" adalah kekuatan yang dapat mempengaruhi tugas dan wewenang Komisi Pemberantasan Korupsi atau anggota Komisi secara individual dari pihak eksekutif, yudikatif, legislatif, pihak-pihak lain yang terkait dengan perkara tindak pidana korupsi, atau keadaan dan situasi ataupun dengan alasan apapun. ${ }^{14}$

Perihal Kedudukan KPK yang independen dalam hal ini merupakan jawaban dari persoalan penegakan hukum kasus korupsi di Indonesia. Pada kebanyakan kasus korupsi kerap melibatkan pejabat tinggi, elit politik, elit ekonomi atau pengusahapengusaha besar. Kondisi ini

13 Tuanakotta Theodorus M, 2009, Menghitung Kerugian Keuangan Negara Dalam Tindak Pidana Korupsi, Salemba Empat, Jakarta, h. 38 .

14 Ermansjah Djaja, 2010, Meredesain Pengadilan Tindak Pidana Korupsi, Cet 1, Sinar Grafika, Jakarta Timur, h. 131. 
menyebabkan Kejaksaan atau Kepolisian sering kali tidak dapat leluasa untuk menegakkan hukum karena terbentur dengan campur tangan (intervensi) pihak lain. Selain itu perkara tindak pidana korupsi yang ditangani KPK akan diadili oleh pengadilan khusus tindak pidana korupsi yang kini diatur dalam UndangUndang Nomor 46 Tahun 2009 tentang pengadilan tindak pidana korupsi. ${ }^{15}$

Dalam Pasal 11 UU KPK disebutkan bahwa Komisi

Pemberantasan Korupsi, berwenang melakukan penyelidikan, penyidikan, dan penuntutan tindak pidana korupsi yang :

1. melibatkan aparat penegak hukum, penyelenggara, dan orang lain yang ada kaitannya dengan tindak pidana korupsi yang dilakukan oleh aparat penegak hukum atau penyelenggara Negara;

a. mendapat perhatian yang meresahkann masyarakat; dan/atau

b. menyangkut kerugian Negara paling sedikit Rp. 1000.000.000,- (satu miliar rupiah).

Berdasarkan Pasal 6 UndangUndang Np 30 Tahun 2002 tentang

15 Darwan Prinst, 2002, Pemberantasan Tindak Pidana Korupsi, P.T Citra Aditya Bakti, Bandung, h. 31.
KPK, KPK mempunyai tugas melakukan :

1. Koordinasi dengan instansi yang berwenang melakukan pemberantasan tindak pidana korupsi

2. Supervisi terhadap instansi yang berwenang melakukan pemberantasan tindak pidana korupsi

3. Melakukan penyelidikan, penyidikan, penuntutan terhadap tindak pidana korupsi

4. Melakukan tindakantindakan pencegahan korupsi

5. Melakukan monitor terhadap penyelenggaraan negara.

\subsection{Dasar Pertimbangan}

Diaturnya Pasal 40 UndangUndang Nomor 30 Tahun 2002 Tentang KPK.

Komisi Pemberantasan Korupsi tidak berwenang mengeluarkan surat perintah penghentian penyidikan dan penuntutan dalam perkara tindak pidana korupsi, begitu bunyi pasal yang tercantum dalam Pasal 40 UU KPK.

Ketidakwenangan KPK dalam mengeluarkan Surat Perintah Penghentian Penyidikan (SP3) melanggar prinsip persamaan di muka hukum serta bersifat diskriminatif, sehingga bertentangan dengan Pasal 28D ayat (1) UUD 1945 yang berbunyi "Setiap orang berhak atas pengakuan, jaminan, perlindungan, dan kepastian 
hukum yang adil serta perlakuan yang sama di hadapan hukum", dan Pasal 281 ayat (2) UUD 1945 yang berbunyi "Setiap orang berhak bebas dari perlakuan yang bersifat diskriminatif atas dasar apa pun dan berhak mendapatkan perlindungan terhadap perlakuan yang bersifat diskriminatif itu”.

SP3 maupun SKP2 seringkali dikeluarkan oleh pihak Kepolisian dan Kejaksaan untuk dijadikan alasan menghentikan perkara korupsi yang sedang ditanganinya. Berdasarkan dalil tersebut UU KPK dengan kewenangan yang dijalankan dengan cara-cara yang tidak biasa yakni dengan tidak diberikannya wewenang kepada KPK untuk mengeluarkan SP3 maupun SKP2 tidak lebih untuk memaksimalkan proses penegakan hukum terhadap tindak korupsi yang sedang KPK tangani. Apabila diberikan kewenangan mengeluarkan SP3 maupun SKP2, maka KPK tidak berbeda dengan Kepolisian maupun Kejaksaan yang mana seringkali dalam penanganan kasusnya terjadinya permainan antar aparatur dengan pihak yang terkait dalam proses pengehentian penyidikan itu sendiri.
Dalam Pasal 44 UU KPK disebutkan bahwa KPK hanya memiliki kewenangan untuk melakukan penghentian penyelidikan terhadap kasus korupsi yang ditanganinya. Mengenai prosedur penghentian penyidikan maupun penuntutan masih merupakan kewenangan penegak hukum yang telah diatur sebelumnya dalam KUHAP (Kepolisian dan Kejaksaan). Ketidakwenangan KPK dalam mengeluarkan SP3 maupun SKP2 adalah bentuk kekhususan dari UU KPK terhadap KUHAP yang biasa kita kenal dengan isitilah lex specialis derogat legi generali dalam arti peraturan yang bersifat khusus mengesampingkan peraturan yang bersifat umum. Pengaturan ini merupakan prosedur khusus yang dimiliki oleh KPK untuk memaksimalkan pemberantasan dan penegakan hukum terhadap kasus kasus korupsi.

Dalam Risalah Rapat Panja Komisi Pemberantasan Tindak Pidana Korupsi, pada tanggal 5 desember 2001, pembahasan RUU Tentang Komisi Pemberantasan Tindak Pidana Korupsi, DR. H. Zain Badjeber selaku anggota Fraksi PPP, menyebutkan bahwa "Komisi ini dengan orang-orang 
terpilih, hukum acaranya juga supaya luar biasa, di dalam konsep kami misalnya Pertama, bahwa jangan hanya menegaskan tidak mempunyai wewenang SP3, maksudnya tidak mempunyai wewenang SP3 itu kan bukan berarti mencabut wewenangnya tetapi supaya semua perkara selesai di pengadilan tidak selesai di tengah jalan. Nanti pengadilan yang mengatakan tidak cukup bukti supaya orang tidak curiga karena sifat inkuisitor dari pada pemeriksaan kita. Jadi terbuka di pengadilan disanalah yang mengatakan tidak cukup bukti sehingga orang ini dibebaskan, tidak cukup bukti ditengah jalan terkatung-katung”.

Berdasarkan Pembahasan RUU Tentang Komisi Pemberantasan Tindak Pidana Korupsi diatas latar belakang pengaturan Pasal 40 UU KPK dapat dilihat dari beberapa faktor. Yang pertama dari faktor filosofis dilatarbelakangi oleh kurang mampunya penegak hukum yang ada dalam hal ini pihak Kepolisian dan Kejaksaan dalam memberantas kasus korupsi yang sedang mereka tangani secara maksimal. Faktor yuridis dimana Pasal 40 UU KPK ini merupakan peraturan yang bersifat khusus dan mengesampingkan peraturan yang bersifat umum dalam hal ini KUHAP. Kekhususan UU KPK ini tidak bertentangan dengan KUHAP karena berlaku asas lex specialis derogat legi generali. Faktor yang terakhir yakni faktor sosiologis dimana KPK selama ini memiliki berberapa kewenangan yang sangat luar biasa, yang tidak dimiliki oleh Kepolisian maupun Kejaksaan yang bertujuan untuk memaksimalkan pemberantasan dan penegakan hukum terhadap kasus-kasus korupsi yang sudah sangat meresahkan. Kewenangan ini tidak lain untuk menciptakan kepastian hukum dalam masyarakat.

Tidak seperti Kepolisian dan Kejaksaan yang merupakan penegak hukum inti di dalam sistem peradilan pidana kita, keberlakuan Pasal 40 UU KPK ini adalah upaya dari keberadaan lembaga KPK yang bukan sebagai aparat penegak hukum namun ikut berperan dalam rangka pemberantasan tindak pidana korupsi. Hal tersebut bertujuan agar KPK ikut ambil bagian dalam penegakan hukum di bidang tindak pidana korupsi, selain itu hal tersebut juga merupakan kewajiban semua pihak, dalam hal ini aparat penegak hukum yang sudah ada bersama semua komponen bangsa. 
Pengaturan Pasal 40 UU KPK merupakan salah satu amunisi yang digunakan oleh KPK dalam proses penyidikan kasus korupsi agar KPK dapat bekerja maksimal dan efisien.

Untuk mencegah negosiasi terselubung antara oknum KPK dengan pihak-pihak yang terkait dalam hal ini tersangka kasus korupsi, adanya Pasal 40 UU KPK ini diharapkan memberikan kepastian hukum dalam penegakan hukum tindak pidana korupsi di Indonesia, sehingga tidak terjadi hal-hal yang tidak diinginkan dalam proses penyidikan yang berlangsung.

Ketentuan Pasal 40 UU KPK merupakan sikap kehatihatian yang harus sangat diperhatikan oleh KPK. Setiap kasus yang telah disidik oleh KPK akan terus berlanjut hingga ke ranah tingkat pengadilan. KPK diwajibkan untuk bekerja secara hatihati dan maksimal berkaitan dengan masalah pembuktian baik dari awal proses penyelidikan hingga akhirnya menetapkan seseorang sebagai tersangka.

Dalam menjalankan tugasnya, selain berpedoman pada UndangUndang tentang KPK dan UndangUndang Pemberantasan Tindak Pidana Korupsi, KPK juga berdasar pada peraturan perundang-undangan mengenai hukum acara pidana yang berlaku di Indonesia, termasuk KUHAP. Pasal 40 Undang-Undang Nomor 30 Tahun 2002 tentang KPK tidak dapat dikatakan bertentangan dengan KUHAP. Undang-Undang No 30 Tahun 2002 tentang KPK merupakan lex specialis (ketentuan yang khusus), yang merupakan buah hasil kebijakan politik hukum pidana (politik kebijakan/criminal policy) dalam menangani tindak pidana korupsi. ${ }^{16}$

\section{PENUTUP}

Berdasarkan pembahasan tersebut di atas, maka pada bagian penutup dapat dikemukakan simpulan dan saran dari penulis sebagai berikut :

\subsection{Simpulan}

KPK tidak diberi wewenang untuk menerbitkan SP3 sesuai dengan Pasal 40 UU KPK dapat dilihat dari beberapa faktor. Yang pertama dari faktor filosofis dilatarbelakangi oleh kurang mampunya penegak hukum yang ada dalam hal ini pihak Kepolisian dan Kejaksaan dalam memberantas kasus korupsi yang sedang mereka tangani secara maksimal. Faktor yuridis

16 Putra Erawan M, 2008, Membangun KPK di Daerah, Makalah disampaikan pada bulan Mei di Denpasar, h. 9. 
dimana Pasal 40 UU KPK ini merupakan peraturan yang bersifat khusus dan mengesampingkan peraturan yang bersifat umum dalam hal ini KUHAP. Kekhususan UU KPK ini tidak bertentangan dengan KUHAP karena berlaku asas lex specialis derogat legi generali. Faktor yang terakhir yakni faktor sosiologis dimana KPK selama ini memiliki berberapa kewenangan yang sangat luar biasa, yang tidak dimiliki oleh Kepolisian maupun Kejaksaan yang bertujuan untuk memaksimalkan pemberantasan dan penegakan hukum terhadap kasuskasus korupsi yang sudah sangat meresahkan. Kewenangan ini tidak lain untuk menciptakan kepastian hukum dalam masyarakat.

\section{Saran}

Seyogyanya ketidakwenangan KPK dalam mengeluarkan SP3 sesuai dengan Pasal 40 UU KPK pada setiap perkara tindak pidana korupsi yang ditanganinya tetap dilaksanakan untuk mencegah adanya permainan antar aparatur dan untuk memberantas tindak pidana korupsi yang semakin merajalela di Indonesia.

\section{DAFTAR PUSTAKA}

\section{BUKU}

Amiruddin, 2008, Pengantar Metode Penelitian Hukum, Cet 4, PT Raja Grafindo Persada, Jakarta.

Chazawi, Adami, 2006, Hukum Pembuktian Tindak Pidana Korupsi, PT. Alumni, Bandung.

Djaja, Ermasjah, 2010, Meredesain Pengadilan Tindak Pidana Korupsi, Cet 1, Sinar Grafika, Jakarta Timur.

Hamzah, Andi, 1991, Korupsi di Indonesia, Masalah dan Pemecahannya, Jilid 1, Cet. 3, Gramedia, Jakarta.

Harun M, Husein 1991, Penyidikan dan Penuntutan Dalam Proses Pidana, Rineka Cipta, Jakarta.

Mahmud Marzuki, Peter, 2006, Penelitian Hukum, Kencana Prenada Media Group, Jakarta.

Masduki, Teten, 2005, Menunggu Gebrakan KPK, Jentera Jilid VIII, Cet 3, Sinar Grafika, Jakarta.

Mulyadi, Lilik, 2007, Hukum Acara Pidana Normatif, Teoritis, Praktik dan Permasalahannya, P.T. Alumni, Bandung. 2007, Tindak Pidana Korupsi di Indonesia, Normatif, Teoritis, Praktik dan Masalahnya, P.T. Alumni, Bandung.

Nowak, Manfred, 2002, Introduction to the International Human Rights Regimen, Brill Academic Publishers, USA.

Prakoso, Djoko, 1987, Penyidik, Penuntut Umum, Hakim, Dalam Proses Hukum Acara Pidana, Bina Aksara, Jakarta. 
Prinst, Darwan, 2002, Pemberantasan Tindak Pidana Korupsi, P.T Citra Aditya Bakti, Bandung.

Theodorus M, Tuanakotta, 2009, Menghitung Kerugian Keuangan Negara Dalam Tindak Pidana Korupsi, Salemba Empat, Jakarta.

Wijaya, Firman, 2008, Peradilan Korupsi Teori dan Praktik, Maharani Press, Jakarta.

\section{MAKALAH}

Erawan M, Putra, 2008, Membangun KPK di Daerah, Makalah disampaikan pada bulan Mei di Denpasar.

\section{INTERNET}

Shanti Rachmadsyah, SP3, http://www.hukumonline.com/klinik/det ail/c1624, diakses Kamis 31 Oktober 2013

Biodata Penulis

Nama : I Dewa Gede Dana Sugama

Alamat : Jl Gatot Subroto VIB no 12

Denpasar, Bali

No. Telp. : 081999779090

E-mail : dewasugama@ymail.com 